\title{
TINGKAT PENDIDIKAN IBU DAN PEMBERIAN ASI EKSKLUSIF DENGAN KEJADIAN STUNTING PADA BALITA DI PROVINSI SULAWESI SELATAN
}

\author{
Analisis Data Sekunder Laporan Pemantauan Status Gizi \\ Provinsi Sulawesi Selatan Tahun 2015 \\ Mustamin ${ }^{1}$, Ramlan Asbar, Budiawan \\ ${ }^{1}$ Jurusan Gizi, Politeknik Kesehatan Kemenkes, Makassar \\ ${ }^{2}$ Alumni Prodi D-IV, Jurusan Gizi, Politeknik Kesehatan Kemenkes, Makassar \\ Korespondensi, E-Mail : mustamin@ poltekkes-mks.ac.id
}

\begin{abstract}
Stunting is caused by three factors, involving individuals' food intake, birth weight and health condition; the quality and quantity of food nutrition, human resources, number and family structure, parenting, health care, and services; and environmental factors that include social infrastructure, educational services and health services. This aimed to find the relationship between mothers' education level and exclusive breastfeeding toward the toddlers' stunting in South Sulawesi Province 2015 based on the report of secondary data analysis on Nutrition Status (PSG) 2015. This research used 2015 PSG data with observational design. The samples in this research were toddlers in 3 cities or regency in South Sulawesi Province with the highest stunting event rate, they were Jeneponto (300 toddlers), Pangkep (300 toddlers) and Tana Toraja (298 toddlers). Secondary data were taken from PSG report of 2015. The nutrition status was measured by anthropometry. Mothers' education level and exclusive breastfeeding data were obtained by asking respondents using PSG 2015 questionnaires. To find out the relationship of two variables, it was conducted yate's correlation test using SPSS program. The data were presented in the form of frequency distribution tables and narration. The results showed that the prevalence of stunting was 44\%. The proportion of lower educated mothers was $56.5 \%$, while exclusive breastfeeding was quite high at $94.8 \%$. Mothers with less education (27.7\%) had stunting children, while $27.3 \%$ well-educated mothers have normal children and there was a significant relationship between mother education level and stunting on toddlers ( $p=0,001)$. The stunting was found on toddlers who are not exclusively breastfed $(0.9 \%)$ and exclusively breastfed (43.1\%), and there was a significant relationship between exclusive breastfeeding and stunting incidence in toddlers $(p=0.000)$.
\end{abstract}

Keywords: educated mothers, giving exclusive breastfeeding and stunting.

\section{PENDAHULUAN}

Riset Kesehatan Dasar pada tahun 2013 menunjukkan bahwa prevalensi stunting secara nasional sebesar $37,2 \%$ (sangat pendek 18,0\% dan pendek 19,2\%), yang berarti terjadi peningkatan dibandingkan tahun 2010 yaitu sebesar $35,6 \%$ (sangat pendek $18,5 \%$ dan pendek $18 \%$ ) dan pada tahun 2007 yaitu sebesar $36,8 \%$ (sangat pendek $18,8 \%$ dan pendek 18,0\%) (Balitbangkes, 2013). Masa balita sering dinyatakan sebagai masa kritis 
dalam rangka mendapatkan sumber daya manusia yang berkualitas, terlebih pada periode 2 tahun pertama merupakan masa emas untuk pertumbuhan dan perkembangan otak yang optimal. Suatu negara jika status gizi anak balitanya baik maka kualitas sumber daya manusianya juga baik dan jika status gizinya jelek, maka kualitas sumber daya manusianya pun akan menurun (Aritonang, 2010).

Status gizi bayi dan balita merupakan salah satu indikator gizi masyarakat dan telah dikembangkan menjadi salah satu indikator kesehatan dan kesejahteraan masyarakat. Hal ini dikarenakan kelompok bayi dan balita sangat rentan terhadap berbagai penyakit kekurangan gizi (Rohmatun, 2014).

Masalah gizi khususnya anak pendek (stunting), menghambat perkembangan anak dengan dampak negatif yang akan berlangsung dalam kehidupan selanjutnya. Anak-anak pendek menghadapi kemungkinan yang lebih besar untuk tumbuh menjadi orang dewasa yang kurang berpendidikan, miskin, kurang sehat dan lebih rentan terhadap penyakit tidak menular. Oleh karena itu, anak pendek merupakan prediktor buruknya kualitas sumber daya manusia yang diterima secara luas, yang selanjutnya menurunkan kemampuan produktif suatu bangsa dimasa yang akan datang (UNICEF, 2012).

Stunting menggambarkan keadaan gizi kurang yang sudah berjalan lama dan memerlukan waktu bagi anak untuk berkembang serta pulih kembali. Sejumlah besar penelitian cross-sectional memperlihatkan keterkaitan antara stunting atau berat badan kurang yang sedang atau berat, perkembangan motorik dan mental yang buruk dalam usia kanak-kanak dini serta prestasi kognitif dan prestasi sekolah yang buruk dalam usia kanak-kanak lanjut (Gibney dkk, 2009).

Data Riset Kesehatan Dasar (Riskesdas) 2013 menunjukkan prevalensi balita stunting di Indonesia mencapai 37\% (terdiri dari 18\% sangat pendek dan 19,2\% pendek) yang berarti terjadi peningkatan tahun $2010(35.6 \%)$ dan tahun 2007 $(36,8 \%)$. Terdapat 20 provinsi diatas prevalensi nasional dengan urutan dari prevalensi tertinggi sampai terendah yang dimana Provinsi Sulawesi Selatan pada urutan ke-13, sedangkan masalah kesehatan masyarakat dianggap berat bila prevalensi pendek sebesar 30-39 persen dan serius bila prevalensi pendek $\geq 40$ persen (WHO 2010).

Berdasarkan laporan PSG Sulawesi Selatan tahun 2014, bahwa jumlah balita yang mengalami stunting sebanyak $35.98 \%$, yaitu pendek $(25.58 \%)$ dan sangat pendek $(10.40 \%)$. Angka balita pendek tingkat Sulawesi Selatan tersebut lebih rendah sekitar 5\% dibandingkan dengan hasil Riskesdas tahun 2013 yang mencapai sekitar $41 \%$. Namun demikian, proporsi balita pendek tersebut masih lebih tinggi dari angka balita pendek tingkat nasional (Riskesdas, 2013) yang hanya mencapai $37.2 \%$, yaitu balita pendek sebesar $19.2 \%$ dan sangat pendek sebesar $18.0 \%$. Kabupaten/kota yang paling rendah angka balita pendek adalah Sidrap (22.49\%) dan Bulukumba (31.88\%). Proporsi balita pendek kedua kabupaten tersebut lebih rendah dari angka nasional (Riskesdas 2013) maupun tingkat Provinsi Sulawesi Selatan. Sebaliknya, kabupaten/kota yang paling tinggi angka balita pendek adalah Takalar $(44.32 \%)$, Bone $(40.31 \%)$ dan (Maros 39,07\%).

Pemberian ASI eksklusif di Indonesia masih jauh dari harapan. Berdasarkan hasil survey dari peneliti masih banyak ibu-ibu yang berada di Kecamatan Kawangkoan yang tidak memberikan ASI eksklusif kepada bayi dan hanya diganti dengan susu formula. Jika bayi mendapatkan makanan pendamping ASI terlalu dini (sebelum enam bulan) maka akan meningkatkan risiko penyakit diare dan infeksi lainnya. 
Selain itu juga akan menyebabkan jumlah ASI yang diterima bayi berkurang, padahal komposisi gizi ASI pada 6 bulan pertama sangat cocok untuk kebutuhan bayi, akibatnya pertumbuhan bayi akan terganggu (Sulistyoningsih, 2011). Data Riskesdas 2013 menunjukan kecenderungan proses mulai menyusu pada anak 0-23 bulan pada tahun 2010 dan 2013, dinilai bahwa proses menyusu kurang dari satu jam yaitu sebesar 29,3\% pada tahun 2010 meningkat menjadi 34,5\% pada tahun 2013.

Latar belakang pendidikan orang tua, baik ayah maupun ibu, merupakan salah satu unsur penting dalam menentukan status gizi anak. Pendidikan ibu disamping merupakan modal utama dalam menunjang perekonomian rumah tangga, juga berperan dalam pola pemberian makan keluarga maupun pola pengasuhan anak (Singarimbun, dalam Handarsari dkk, 2010).

Hasil PSG Sulsel tahun 2014 menyatakan bahwa proporsi balita gizi kurang maupun gizi buruk cenderung mengalami penurunan seiring peningkatan pendidikan ibu. Artinya, semakin tinggi tingkat pendidikan ibu maka semakin baik status gizi balitanya. Kemudian untuk hasil PSG Sulsel tahun 2015, menunjukkan bahwa sebagian besar ayah dan ibu memiliki latar belakang pendidikan Tamat SMA yaitu masing-masing $33.5 \%$ dan $29.6 \%$.

Berdasarkan hal tersebut maka penulis bermaksud mempelajari hubungan tingkat pendidikan ibu dan pemberian ASI eksklusif dengan kejadian stunting pada balita di Provinsi Sulawesi Selatan Tahun 2015. Pada hasil Pemantauan Status Gizi (PSG) Sulawesi Selatan tahun 2015 tersedia data tingkat pendidikan ibu, data pemberian ASI eksklusif dan data balita stunting.

\section{METODE}

Penelitian ini menggunakan data PSG 2015. Desain yang digunakan dalam penelitian ini yaitu observasional. Variabel independen dan dependen diukur pada saat bersamaan pada waktu PSG berlangsung.

Kegiatan PSG 2015 telah dilakukan sejak bulan Oktober sampai Desember tahun 2015 di kabupaten dan kota Provinsi Sulawesi Selatan, sedangkan analisis lanjut data PSG ini (data sekunder) dilakukan pada bulan Maret sampai Mei 2017.

Populasi dalam penelitian adalah seluruh balita yang masuk dalam populasi PSG 2015 sebanyak 7.200 balita.Sampel dalam penelitian ini adalah balita yang berada di 3 kota atau kabupaten di Provinsi Sulawesi Selatan dengan angka kejadian stunting tertinggi, yaitu Jeneponto (300 balita), Pangkep (300 balita) dan Tana Toraja (298 balita).

Status gizi balita diukur dengan cara antropometri. Data tingkat pendidikan ibu dan pemberian ASI eksklusif diperoleh dengan menanyakan responden menggunakan kuesioner PSG 2015. Untuk mengetahui hubungan dua variable dilakukan uji yate's correlation dengan menggunakan program SPSS. Data disajikan dalam bentuk tabel distribusi frekuensi dan narasi.

\section{HASIL Usia Sampel}

Tabel 1.

Distribusi Balita Berdasarkan Usia

\begin{tabular}{ccc}
\hline Usia & $\mathrm{n}$ & $\mathbf{\%}$ \\
\hline $0-5$ Bulan & 146 & 16.3 \\
$6-11$ Bulan & 127 & 14.1 \\
$12-23$ Bulan & 223 & 24.8 \\
$24-60$ Bulan & 402 & 44.8 \\
\hline Total & 898 & 100 \\
\hline
\end{tabular}

Berdasarkan Tabel 1 menunjukkan bahwa sampel terbanyak berumur $24-60$ bulan sebanyak 402 balita $(44,8 \%)$ dan 
terendah berumur $6-11$ bulan sebanyak 127 balita $(14,1 \%)$.

Jenis Kelamin

Tabel 2.

Distribusi Balita Berdasarkan Jenis

Kelamin

\begin{tabular}{ccc}
\hline \hline Jenis kelamin & $\mathrm{n}$ & $\boldsymbol{\%}$ \\
\hline Laki - laki & 470 & 52.3 \\
Perempuan & 428 & 47.7 \\
\hline Total & 898 & 100 \\
\hline
\end{tabular}

Berdasarkan Tabel 2 menunjukkan bahwa sampel lebih banyak berjenis kelamin laki-laki yaitu 470 balita $(52,3 \%)$, dibandingkan perempuan sebanyak 428 orang $(47,7 \%)$.

\section{Pendidikan Responden/Ibu Balita}

Tabel 3

Distribusi Responden Berdasarkan Pendidikan

\begin{tabular}{lcc}
\hline \hline \multicolumn{1}{c}{ Pendidikan } & $\mathrm{n}$ & $\mathbf{\%}$ \\
\hline Tidak Pernah Sekolah & 25 & 2.8 \\
Tidak Tamat SD & 30 & 3.3 \\
Tamat SD & 254 & 28.3 \\
Tamat SMP & 198 & 22 \\
Tamat SMA & 269 & 30 \\
Tamat D1-D3 & 33 & 3.7 \\
Tamat DIV/S1-S3 & 89 & 9.9 \\
\hline \multicolumn{1}{c}{ Total } & 898 & 100 \\
\hline
\end{tabular}

Berdasarkan Tabel 3 menunjukkan bahwa pada umumnya responden berpendidikan tamat SMA sebanyak 269 orang (30\%) dan ada 25 orang $(2,8 \%)$ yang tidak pernah bersekolah.

\section{Kategori Pendidikan Responden/Ibu Balita}

Tabel 4

Distribusi Responden Berdasarkan Kategori Pendidikan

\begin{tabular}{lcc}
\hline \hline $\begin{array}{c}\text { Kategori } \\
\text { Pendidikan }\end{array}$ & $\mathrm{n}$ & $\boldsymbol{\%}$ \\
\hline Baik & 391 & 43.5 \\
Kurang & 507 & 56.5 \\
\hline \multicolumn{1}{c}{ Total } & 898 & 100 \\
\hline
\end{tabular}

Berdasarkan Tabel 4 menunjukkan bahwa pada umumnya kategori pendidikan responden kurang sebanyak 507 orang $(56,5 \%)$ dan 391 orang $(43,5 \%)$ responden yang kategori pendidikannya baik.

\section{Pemberian ASI Eksklusif}

Tabel 5

Distribusi Responden Berdasarkan Pemberian ASI Eksklusif

\begin{tabular}{lcc}
\hline \hline $\begin{array}{c}\text { Pemberian ASI } \\
\text { Eksklusif }\end{array}$ & $\mathrm{n}$ & $\boldsymbol{\%}$ \\
\hline Ya & 851 & 94.8 \\
Tidak & 47 & 5.2 \\
\hline Total & 898 & 100 \\
\hline
\end{tabular}

Tabel 5 menunjukkan sebagian besar ibu balita $(94,8 \%)$ memberikan ASI secara eksklusif dan hanya 5,2 \% ibu balita yang tidak memberikan ASI secara eksklusif.

Status Gizi Balita Berdasarkan Indeks PB(TB)/U

Tabel 6

Distribusi Sampel Berdasarkan Status Gizi (Indeks PB(TB)/U)

\begin{tabular}{ccc}
\hline \hline Status Gizi & $\mathrm{n}$ & $\boldsymbol{\%}$ \\
\hline Normal & 503 & 56 \\
Stunting & 395 & 44 \\
\hline Total & 898 & 100 \\
\hline
\end{tabular}


Berdasarkan Tabel 6 menunjukkan bahwa pada umumnya status gizi sampel berdasarkan inddeks $\mathrm{PB}(\mathrm{TB}) / \mathrm{U}$ paling banyak berstatus gizi normal sebanyak 503 balita (56 \%) dan 395 balita (44\%) yang dinyatakan stunting.

\section{Hubungan Pendidikan Ibu Terhadap Kejadian Stunting}

Tabel 7

Distribusi Pendidikan Ibu Terhadap Kejadian Stunting

\begin{tabular}{|c|c|c|c|c|c|c|c|c|}
\hline \multirow{3}{*}{$\begin{array}{c}\text { Status Gizi } \\
\text { Menurut } \\
\mathrm{PB}(\mathrm{TB}) / \mathrm{U}\end{array}$} & \multicolumn{4}{|c|}{ "Pendidikan } & \multirow{2}{*}{\multicolumn{2}{|c|}{ Jumlah }} & \multirow{3}{*}{$\begin{array}{l}\text { Continuity } \\
\text { Correction }\end{array}$} & \multirow{3}{*}{$p$} \\
\hline & \multicolumn{2}{|c|}{ Baik } & \multicolumn{2}{|c|}{ Kurang } & & & & \\
\hline & $\mathrm{n}$ & $\%$ & $\mathrm{n}$ & $\%$ & $\mathrm{n}$ & $\%$ & & \\
\hline Normal & 245 & 27.3 & 258 & 28.7 & 503 & 56 & & 0001 \\
\hline Stunting & 146 & 16.3 & 249 & 27.7 & 395 & 44 & & 01 \\
\hline Jumlah & 391 & 43.6 & 507 & 56.4 & 898 & 100 & & \\
\hline
\end{tabular}

Berdasarkan Tabel 7 menunjukkan bahwa hasil analisis statistik dengan menggunakan uji Chi-square ini diketahui bahwa ada hubungan yang bermakna antara pendidikan ibu dengan kejadian stunting pada balita di Provinsi Sulawesi Selatan Tahun 2015 berdasarkan analisis data sekunder Laporan Pemantauan Status Gizi (PSG) tahun 2015.

Pada penelitian ini menunjukkan bahwa dari 507 balita dengan ibu berpendidikan kurang memiliki indeks ZSkor $\mathrm{PB}(\mathrm{TB}) / \mathrm{U} \quad$ stunting $\quad(27,7 \%)$, sedangkan dari 391 balita dengan ibu berpendidikan baik sebagian besar memiliki indeks Z-Skor PB(TB)/U normal $(27,3 \%)$. Berdasarkan hasil analisis menghasilkan $p<0,05$ dengan nilai signifikansi 0,001 yang berarti signifikan atau bermakna. Hal ini berarti ada hubungan antara tingkat pendidikan ibu dengan kejadian stunting pada balita di Provinsi Sulawesi Selatan Tahun 2015 berdasarkan analisis data sekunder Laporan Pemantauan Status Gizi (PSG) tahun 2015.

\section{Hubungan Pemberian ASI Eksklusif Terhadap Kejadian Stunting}

Tabel 8

Distribusi Pemberian ASI Eksklusif Terhadap Kejadian Stunting

\begin{tabular}{ccccccccc}
\hline \hline Status Gizi & \multicolumn{4}{c}{ Pemberian ASI } \\
Menurut & \multicolumn{4}{c}{ Eksklusif } & \multirow{4}{*}{ Jumlah } & $\begin{array}{c}\text { Continuity } \\
\text { PB(TB)/U }\end{array}$ & \multicolumn{3}{c}{ Ya } & \multicolumn{4}{c}{ Tidak } & & \\
\cline { 2 - 7 } & $\mathrm{n}$ & $\%$ & $\mathrm{n}$ & $\%$ & $\mathrm{n}$ & $\%$ & & \\
\hline Normal & 464 & 51.7 & 39 & 4.3 & 503 & 56 & \multirow{2}{*}{13.505} & \multirow{2}{*}{0.000} \\
Stunting & 387 & 43.1 & 8 & 0.9 & 395 & 44 & & \\
\hline Jumlah & 851 & 94.8 & 47 & 5.2 & 898 & 100 & & \\
\hline
\end{tabular}

Berdasarkan Tabel 8 menunjukkan bahwa hasil analisis statistik dengan menggunakan uji Chi-square ini diketahui bahwa ada hubungan yang bermakna antara pemberian ASI eksklusif dengan kejadian stunting pada balita di Provinsi 
Sulawesi Selatan Tahun 2015 berdasarkan analisis data sekunder Laporan Pemantauan Status Gizi (PSG) tahun 2015.

Pada penelitian ini menunjukkan bahwa dari 851 balita yang mendapatkan ASI eksklusif sebagian besar memiliki indeks Z-skor PB(TB)/U normal $(51,7 \%)$ sedangkan dari 47 balita yang tidak mendapatkan ASI eksklusif memiliki indeks $\mathrm{PB}(\mathrm{TB}) / \mathrm{U}$ stunting $(0,9 \%)$. Berdasarkan hasil analisis menghasilkan $p$ $<0,05$ dengan nilai signifikansi 0,000 yang berarti signifikan atau bermakna. Hal ini berarti ada hubungan yang bermakna antara pemberian ASI eksklusif dengan kejadian stunting pada balita di Provinsi Sulawesi Selatan Tahun 2015 berdasarkan analisis data sekunder Laporan Pemantauan Status Gizi (PSG) tahun 2015.

\section{PEMBAHASAN}

Stunting merupakan hasil dari kekurangan gizi kronis, yang menghambat pertumbuhan linear. Biasanya, pertumbuhan goyah dimulai pada sekitar usia enam bulan, sebagai transisi makanan anak yang sering tidak memadai dalam jumlah dan kualitas, dan peningkatan paparan dari lingkungan yang meningkatkan terkena penyakit. (Elizabeth, 2013). Menurut WHO (2010) stunting disebabkan oleh malnutrisi dan atau penyakit infeksi kronis yang berulang.

Penelitian ini menunjukkan adanya 395 balita (44\%) yang dinyatakan stunting. Angka ini merupakan angka yang relatif tinggi jika dibandingkan dengan target Millenium Development Goals (MDGs) yaitu $15 \%$.

Pada penelitian ini menunjukkan bahwa dari 507 balita dengan ibu berpendidikan kurang memiliki indeks ZSkor $\mathrm{PB}(\mathrm{TB}) / \mathrm{U}$ stunting $(27,7 \%)$, sedangkan dari 391 balita dengan ibu berpendidikan baik sebagian besar memiliki indeks Z-Skor PB(TB)/U normal $(27,3 \%)$. Berdasarkan hasil analisis menghasilkan $p<0,05$ dengan nilai signifikansi 0,001 yang berarti signifikan atau bermakna. Hal ini berarti ada hubungan antara tingkat pendidikan ibu dengan kejadian stunting pada balita di Provinsi Sulawesi Selatan Tahun 2015 berdasarkan analisis data sekunder Laporan Pemantauan Status Gizi (PSG) tahun 2015. Hasil tersebut sependapat dengan naskah publikasi oleh Rohmatun (2014) yang mengatakan bahwa ada hubungan antara tingkat pendidikan ibu dengan kejadian stunting pada balita di Desa Sidowarno Kecamatan Wonosari Kabupaten Klaten dengan nilai signifikansi 0,007 .

Tingginya tingkat pendidikan yang dimiliki maka akan mempengaruhi pengetahuan tentang gizi. Hasil laporan PSG Sulsel tahun 2015 mengatakan bahwa semakin rendah tingkat pendidikan ibu maka proporsi masalah gizi balita semakin tinggi, begitu pula sebaliknya. Hal tersebut menunjukkan bahwa tingkat pendidikan ibu salah satu komponen yang tidak bisa diabaikan. Pengetahuan ibu tentang gizi berpengaruh pada perilaku ibu dalam menyediakan makanan bagi anaknnya. Ibu yang memiliki pengetahuan gizi baik diharapkan mampu menyediakan makanan dengan jenis dan jumlah yang tepat agar anak dapat tumbuh dan berkembang secara optimal (Astari, 2008).

Pada penelitian ini menunjukkan bahwa dari 851 balita yang mendapatkan ASI eksklusif sebagian besar memiliki indeks Z-skor $\mathrm{PB}(\mathrm{TB}) / \mathrm{U}$ normal $(51,7 \%)$ sedangkan dari 47 balita yang tidak mendapatkan ASI eksklusif memiliki indeks $\mathrm{PB}(\mathrm{TB}) / \mathrm{U}$ stunting $(0,9 \%)$. Berdasarkan hasil analisis menghasilkan $p$ $<0,05$ dengan nilai signifikansi 0,000 yang berarti signifikan atau bermakna. Hal ini berarti ada hubungan yang bermakna antara pemberian ASI eksklusif dengan kejadian stunting pada balita di Provinsi Sulawesi Selatan Tahun 2015 berdasarkan analisis data sekunder Laporan Pemantauan Status Gizi (PSG) tahun 2015. 
Hasil tersebut sependapat dengan Dewi (2015) yang mengatakan bahwa ada hubungan status stunting dengan pemberian ASI Eksklusif pada balita di Kabupaten Gunung Kidul dengan nilai signifikansi 0,002.

Hasil laporan PSG tahun 2015 mengatakan bahwa balita yang tidak ASI eksklusif sebagian besar (3,8\%) mendapatkan susu formula pada usia 0 bulan. Pemberian ASI bersamaan dengan susu formula dapat memenuhi kebutuhan zat gizi bayi sehingga pertumbuhannya tidak terganggu. Akan tetapi, susu formula tidak mengandung zat antibodi sebaik kandungan zat antibodi pada ASI sehingga bayi lebih rentan terkena penyakit (Rahayu, 2011).

\section{KESIMPULAN}

1. Berdasarkan kategori pendidikan, proporsi ibu berpendidikan kurang lebih tinggi $(56,5 \%)$ dibandingkan dengan ibu berpendidikan baik.

2. Pemberian ASI eksklusif sudah cukup tinggi mencapai $94,8 \%$.

3. Prevalensi stunting pada penelitian ini cukup tinggi yaitu $44 \%$.

4. Ibu berpendidikan kurang $(27,7 \%)$ memiliki balita stunting, sementara 27,3\% ibu berpendidikan baik memiliki balita normal dan terdapat hubungan signifikan antara tingkat pendidikan ibu dengan kejadian stunting pada balita.

5. Stunting ditemukan pada balita yang tidak diberikan ASI eksklusif $(0,9 \%)$ dan yang diberi ASI eksklusif (43,1 $\%$ ), dan terhadap hubungan signifikan antara pemberian ASI eksklusif dengan kejadian stunting pada balita.

\section{SARAN}

1. Diharapkan kepada petugas kesehatan dapat meningkatkan monitoring pertumbuhan balita sehingga dapat mengurangi risiko terjadinya stunting pada balita.
2. Diharapkan bagi seluruh masyarakat agar mempertahankan pemberian ASI eksklusif pada balita dan mengoptimalkan pelaksanaan UU Kesehatan 2009 yang terdapat sanksi tegas pada siapa yang dengan sengaja menhalangi program pemberian ASI Eksklusif (Pasal 200) dan sangsi pidana berat bagi korporasi (Pasal 201) serta pelaksanaan PP no. 33 tahun 2012 tentang ASI.

3. Diharapkan peranan petugas kesehatan lebih ditingkatkan lagi dalam hal pelaksanaan penimbangan, pengukuran tinggi badan dan imunisasi serta juga memberikan edukasi kepada ibu balita mengenai pentingnya perhatian terhadap pertumbuhan balita.

\section{DAFTAR PUSTAKA}

Arisman, M. B. 2010. Gizi Dalam Daur Kehidupan. Edisi 2. Penerbit Buku EGC. Jakarta.

Aritonang, I. 2010. Menilai Status Gizi Untuk Mencapai Sehat Optimal. Grafina Mediacipta, Cv.

Astari, LD. 2008. Faktor-faktor yang Berpengaruh Terhadap Kejadian Stunting Balita Usia 6-12 Bulan di Kabupaten Bogor (Tesis). Institut Pertanian Bogor : Bogor.

Budiasih, S. 2008. Hanbook Ibu Menyusui. Bandung. Karya Kita.

Damanik, M. Rizal, Ikeu Ekayanti, Didik Hariyadi. 2010. Analisis Pengaruh Pendidikan Ibu Terhadap Status Gizi Balita Di provinsi Kalimantan Barat. Jurnal Gizi dan Pangan

Depkes RI. 2004. Pedoman Gizi Seimbang. Jakarta : Dirjen Kesmas

Dewi, Devillya Puspita. 2015. Status Stunting Kaitannya dengan Pemberian ASI Eksklusif pada Balita di Kabupaten Gunung Kidul. Vol X Nomor 4 Oktober 2015 Jurnal Medika Respati 
Elizabeth. 2013. Gambaran sosial ekonomi keluarga anak balita pendek (stunting) dikelurahan sudiang raya kecamatan biringkanaya kota makassar. Karya Tulis Ilmiah. Jurusan Gizi Politeknik Kesehatan Makassar Program studi diploma III Gizi.

Fanny, L., Aswita A, dan Theresia D. KB. 2009. Gizi Dalam Daur Kehidupan. Politeknik Kesehatan Makassar Jurusan Gizi Makassar

Gibney, M. J., Margetts, Barrie M., Kearny, John M., dan Arab L. 2009. Public Health Nutrition (Gizi Kesehatan Masyarakat).EGC. Jakarta

Handarsari, E., Rosidi, A., dan Widyaningsih, J. 2010. Hubungan Pendidikan dan Pengetahuan Gizi Ibu dengan Tingkat Konsumsi Energi dan Protein Anak TK Nurul Bahri Desa Wukir Sari Kecamatan Batang Kabupaten Batang. Program Studi DIII Gizi Fakultas Ilmu Keperawatan dan Kesehatan Universitas Muhammadiyah Semarang

Kemenko KesRa RI. 2012. Pedoman Perencanaan Program Gerakan Nasional Sadar Gizi dalam Rangka 1000 Hari Pertama Kehidupan. Diakses 3 Januari 2017 dari : http://www.bappenas.go.id

Notoatmodjo, S. 2012. Promosi Kesehatan dan Perilaku Kesehatan.Jakarta : Rineka Cipta.

Rahayu, L. S. 2011. Associated ofHeight of Parents WithChanges of Stunting Statusfrom 6-12 months to 34years (Tesis). Yogyakarta :Universitas Gajah Mada Yogyakarta.

Riskesdas. 2013. Laporan Nasional Riset Kesehatan Dasar (Riskesdas Tahun 2013). Jakarta : Badan Penelitian dan Pengembangan Kesehatan Departemen Kesehatan RI.

Rohmatun, N. Y. 2014. Hubungan Tingkat Pendidikan Ibu Dan Pemberian ASI Eksklusif Dengan Kejadian Stunting Pada Balita Di Desa Sidowarno Kecamatan Wonosari Kabupaten Klaten. Naskah Publikasi Program Studi Gizi Fakultas Ilmu Kesehatan Universitas Muhammadiyah Surakarta.

Sulistyoningsih, H. 2011. Gizi Untuk Kesehatan Ibu dan Anak. Yogyakarta : Graha Ilmu.

UU RI No. 20. 2003. Sistem Pendidikan Nasional.

UNICEF. 2012. Ringkasan Kajian Gizi Ibu Dan Anak. UNICEF Indonesia. Jakarta

WHO. 2006. Situation :Underweight In Children In Global Healhty Observatory.

WHO. 2010. Infant mortality. World Health Organization 